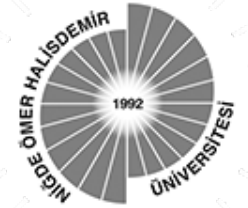

Araştırma Makalesi Research Article
Ömer Halisdemir Üniversitesi İktisadi ve İdari Bilimler Fakültesi Dergisi

Yll: 2020 Cilt-Sayl: 13(3) ss: 446-461

Academic Review of Economics and Administrative Sciences

Year: 2020 Vol-Issue: 13(3) pp: 446-461

http://dergipark.org.tr/tr/pub/ohuiibf/

\title{
KonaKlama İşletmelerinde Hizmet Hatasi Telafi STRATEJILERININ KuRUMSAL İTiBARA ETKISI
}

\author{
Erkan $A K G \ddot{O} Z^{1}$ \\ Darya KRASNIKOVA ${ }^{2}$
}

\section{$\ddot{O} z$}

Bu araştırma insan gücüne dayalı ürün ve hizmet üreten işletmelerde gerçekleşen hizmet hatalarını, bunların telafisi ile ilgili ne gibi stratejilerin uygulandığını belirlemek için hazırlanmıştır. Araştırmanın bir diğer amacı da hizmet hatası stratejilerinin kurumsal itibara etkisini belirlemektir. Bunun için de turizm faaliyetine katılanlara yönelik bir araştırma gerçekleştirilmişstir. Araştırma için gerekli veriler tek bir kişiye ya da alana bağlı kalınmadan, bireysel olarak 392 kişinin anket sorularına vermiş olduğu cevaplardan elde edilmiștir. Elde edilen verilere göre hataların büyük bir bölümü temizlik ve hijyen kaynakl olduğu, bununla birlikte işletmelerde kullanılan araç ve gereçlerin arızalı, eksik veya kalitesiz olmasından kaynaklandığı saptanmıștır. Konaklama işletmelerinde karşılaşllan hataların çoğunlukla restoran, ön büro ve kat hizmetleri departmanlarında olduğu da belirlenmiştir. Hizmet hatası ile karşılaşanlar ise sorun veya şikâyetlerini sirasiyla hizmet sunan personele, işletme yetkilisine ve departman sorumlularina iletmektedirler. Turizm faaliyetine katılanlar işletmelerde karşılaşmış oldukları olumsuzlukları ailesine, yakın arkadaşlarına veya çevresindeki insanlara anlatarak göstermektedirler. Araştırmada turizm faaliyetine kattlanlar hizmet hatası ile karşılaştıkları işletmeye tekrar gitmek istemediklerini de belirtmektedirler.

Anahtar Kelimeler $\quad$ : Konaklama, Kurumsal İtibar, Hizmet Hatasi.

Jel Siniflandirilmasi $\quad$ : L83, L14.

\footnotetext{
${ }^{1}$ Doç. Dr. Selçuk Üniversitesi/Kırgızistan-Türkiye Manas Üniversitesi, eakgoz@selcuk.edu.tr, erkan.akgoz@manas.edu.kg, ORCID: http://0000-0001-6723-0271

${ }^{2}$ Kırgızistan-Türkiye Manas Üniversitesi., krada9517@gmail.com, ORCID: 0000-0002-2982-7170.
} 


\title{
The Impact Of Service Failure Compensation STRATEgIES ON CORPORATE REPUTATION IN ACCOMMODATION BUSINESSES
}

\begin{abstract}
This research has been prepared to determine the service failures that occur in businesses producing manpower based products and services and what strategies are applied to compensate them. Another purpose of the study is to measure the impact of service failure strategies on corporate reputation. In order to determine this, a research has been carried out for those participating in tourism activities. The data required for the study were obtained from 392 individual answers to the questionnaire regardless of a single person or field. According to the data, most of the failures were caused by cleaning and hygiene, however, it was determined that the tools and equipment used in the businesses were defective, incomplete or of poor quality. The majority of the failures encountered in the accommodation businesses were determined in the restaurant, front office and housekeeping departments. Those who encounter a service failure convey their problems or complaints to the personnel who provides the services, the business manager and the department head respectively. Participants in tourism activities show their family, close friends or the people around them and show the negativity they encounter in the businesses. In the study, it was also determined that those who participate in tourism activities do not want to go to the business where they encounter service failure.
\end{abstract}

Keywords : Accommodation, Corporate Reputation, Service Failure.

Jel Classification

: L83, L14.

\section{GİRIŞ̧}

İnsanların farklı ihtiyaçlarını karşılamak için kurulan değiş-tokuş sistemi ilk çağlardan beri yürütülmektedir. Bundan dolayı da ürün ve hizmet üreten işletmeler arasında büyük bir rekabet yaşanmaktadır. İşletmeler bu ortamda faaliyetlerini sürdürülebilir hale getirebilmek için yoğun gayret göstermektedirler (Ekici \& Yüce, 2007). Son yıllarda arz kapasitesinin artması ve tüketicilerin bilinçlenmesiyle birlikte sektörler ve işletmeler arasındaki rekabet daha da artmıştır. Bu durum pazarlama faaliyetlerinde de bir takım değişikliğin oluşmasına neden olmuştur. Müşteri odaklı olan, müşteri isteklerini ve memnuniyetini dikkate alan pazarlama yaklaşımı daha fazla önemsenmeye başlamıştır. Mevcut ve potansiyel tüketicilerinin ihtiyaç duyduğu ürün ve hizmetleri rakip işletmelerden daha uygun ortam ve sürede karşılayan işletmeler hem kârlılıklarını hem de örgütsel amaçlarını daha kolay gerçekleştirmektedirler (Torlak, Altunışık, \& Özdemir, 2014). Çünkü günümüz şartlarında faaliyet gösteren her işletme, hangi sektörde faaliyet gösterirse göstersin temel amacı müşterilerinin beklentilerini en etkin şekilde karşılamaktır. Ancak müşteri istekleri karşılanırken bazen bilerek bazen de bilmeyerek bir takım olumsuzluklar yaşanmaktadır. Bu olumsuzluklar hem kurumsal itibarın zarar görmesine hem de işletmenin hedeflerinden uzaklaşmasına neden olmaktadır. İlgili literatüre göre bu tür olumsuzluklar genel olarak hizmet hatası olarak tanımlanmaktadır. Hizmet hatası kavramı sadece ürün ve hizmetlerin üretim veya sunumundaki eksiklikler ya da yanlışlıkları değil, müşteri beklentilerinin karşılanmadığ durumları ifade etmek için de kullanılmaktadır.

Hazırlanan bu çalışmada öncelikle itibar ve hizmet hatası kavramları ile ilgili genel bilgiler verilmiştir. Hizmet hataları sınıflandırıldıktan sonra özellikle insan gücüne dayalı ürün ve hizmet üreten turizm işletmelerinde, hizmet hatalarının telafisi için ne gibi stratejilerin uygulandığ araştırılmıştır. Çünkü hizmet hatalarının telafi edilmesi, işletmelerin kurumsal itibarını olumlu yönde etkilemektedir. Güçlü bir kurumsal itibar ise işletmelerin hem ekonomik hem de sosyal hedeflerine ulaşmasında önemli bir rekabet aracı olarak kabul edilmektedir. 


\section{I. İTIBAAR VE KURUMSAL ITTIBAR}

\section{I.I. İtibar Kavramı}

İtibar, herhangi bir kişi veya kuruma çevresinin göstermiş olduğu saygı ve değer olarak tanımlanmaktadır (Kadıbeşegil, 2006). Olumlu izlenim olarak da ifade edilen itibar; kişi veya kurumların hem iç hem de diş çevresiyle gerçekleştirmiş olduğu etkileşim süreci sonucu oluşmaktadır (Karaköse, 2007: 54). İtibarın oluşması tüm paydaşlarıyla tutarlı ve ilkeli ilişkiler ile gerçekleşmektedir. Zor elde edilen ancak çabuk zarar gören itibar, piyasa şartlarına göre süreç içerisinde gelişip değişmektedir.

İtibar, bir kurumun ya da endüstrinin genel değerler dizisine dayanan güvenilirliği, güvene layık oluşu, sorumluluğu ve yeterliliği (gücü) hakkında çok sayıda kişisel ve ortak yargılardan oluşmuş bir bütün olarak tanımlanmaktadır (Okay \& Okay, 2005). Çoğunlukla dış çevrenin olumlu tutum ve davranışları ile oluşan itibar, kişi veya kurumların kendi kendisini övmesi veya olumlu mesajlar vermesi asla tek başına yeterli olmaz (Kadıbeşegil, 2006). Çünkü itibar bireysel değerler ile toplumsal değerlerin etkileşim sonucu oluşur (Karaköse, 2007).

Zaman içerisinde güç şartlarda oluşan itibar kişi veya kurumlara faaliyet gösterdiği her alanda önemli avantajlar sağlar. Ancak itibar kaybı veya zarar görmesi durumunda da işletmelere veya kişilere birçok dezavantajlar oluşturur. Soyut bir kavram olan itibar, hedeflere ulaşma konusunda hem iç hem de dış çevre üzerinde oluşan olumlu izlenimlerin toplamı olarak da kabul edilmektedir.

\section{I.II. Kurumsal İtibar Kavramı}

Bireysel itibar ile benzer özelliklere sahip olan kurumsal itibar, işletmelerin tüm paydaşları ile olan faaliyetleri sonucu oluşmaktadır. Kurumsal itibar işletmelerin ürün tedarik ettiği veya hizmet sunduğu kişi, kurum ve kuruluşlar nezdinde edindiği statü ve olumlu izlenimlerdir (Aydemir, 2008: 28). Günümüz piyasa şartları dikkate alındığında etkin bir kurumsal itibarın oluşturulması, işletmelere birçok kolaylık sağlayacağı herkes tarafından kabul edilmektedir. Bundan dolay1 profesyonel yönetilen işletmeler klasik yönetimden uzaklaşıp, kurumsal itibarı olumlu yönde etkileyecek özel departmanlar kurmakta, uzmanlar istihdam etmekte yada profesyonel destek almaktadırlar (Karakılıç, 2005: 185). Yönetim anlayışı, organizasyon yapısı veya mali gücü böyle bir yapılaşmaya müsait olmayan kurumlar ise itibar yönetimi konusunu halkla ilişkiler departmanı aracılığı ile gidermeye çalışmaktadırlar. Bunun haricinde de reklam ve tanıtım etkinliklerine ağırlık vermektedirler.

İtibarı önemseyen kurumlar sadece tüketicileri ile değil, çalışanları, iş ortakları ve yatırımcılarıyla ilişkilerine de önem vermektedirler. Özellikle dış hedef kitle olarak kabul edilen kesimle gerçekleştirilen olumlu etkileşimler, işletmelere önemli avantajlar kazdırmaktadır. Bu üstünlükler aşağıdaki gibi özetlenmektedir:

$\checkmark$ Kalifiye personel istihdamı kolaylaşır.

$\checkmark$ Ürün ve hizmetlerin satışı artar.

$\checkmark$ Her türlü faaliyet esnasında oluşabilecek olumsuzluklar daha kolay tolare edilir.

$\checkmark$ Tedarikçiler nezdinde kredibilitesi yükselir.

$\checkmark$ Kriz yönetimini kolaylaştırır.

$\checkmark$ Yerli ve yabancı ortaklarla iş yapma şansını artırır.

$\checkmark$ Kuruma maddi değer katar.

$\checkmark$ Kurumun güvenirliğini artırır (Rose \& Thomsen, 2004; Kadıbeşegil, 2006; Karaköse, 2007; Munyoro \& Magada, 2016).

Kurumsal itibarı etkileyen unsurlar işletmenin büyüklüğü, geçmiş dönemlerdeki performansı, risk profili, medyanın kullanımı, sosyal sorumluluk faaliyetleri ve hukuki düzenlemelere karşı tavrı şeklinde sıralanmaktadır (Williams, Schnake, \& Fredenberger, 2005). Bu gibi unsurlar ile birlikte iç 
ve dış paydaşlarla gerçekleşen etkileşim sonucundaki görüş ve algılar da kurumsal itibarın oluşmasında etkili olmaktadır. Çalışanlar ile yatırımcılar kurumların iç paydaşları olurken, işletmenin ürün ve hizmet üretimi için gerekli olan hammaddeyi sağlayan tedarikçiler, pazarlamacılar, ürün ve hizmetleri satın alan müşteriler de dış paydaşları ifade etmektedir (Saylı \& Uğurlu, 2007). Paydaşların farklı özellikleri ve beklentileri olduğundan, kurumsal itibar da hem iç hem de dış paydaşlar tarafindan farklı algılanabilir (Akgöz \& Solmaz 2010: 26). Kurumsal itibarın kim tarafından nasıl algılandığını bilmek önemlidir. Çünkü bunları doğru analiz etmek ve yorumlamak, kurumsal itibarın etkin yönetilmesini kolaylaştırmaktadır.

\section{HIZMET HATASI VE TELAFİ STRATEJILERİ}

Son dönemlerde ekonomik yatırımların büyük bir bölümü hizmet sektörüne yapılmaktadır. $\mathrm{Bu}$ sektörde insan ihtiyaçları genel olarak emek yoğun olarak karşılanmaktadır. Makinalaşmaya gitmek ve standart bir kalitede üretim gerçekleştirmek oldukça zordur. Bundan dolayı hizmet hatalarının sınıflandırılması, hatalar sonucu oluşan tepkiler, bunların telafi edilmesi gibi konular açıklanması büyük önem arz etmektedir.

\section{II.I. Hizmet Hatası Kavramı ve Sinıflandırılması}

Hizmet hatası, hizmet temini sürecinin herhangi bir aşamasında ortaya çıkan eksiklik veya başarısızlıklardan dolayı tüketici beklentilerinin karşılanamaması olarak tanımlanmaktadır (Olcay \& Özekici, 2015: 1254). Hizmet hatası ürün ve hizmet sağlayan kurumların çalışma şartlarından, personelinden veya diğer müssterilerden kaynaklanan memnuniyetsizliği de ifade etmektedir (Bateson \& Hoffman, 2011). İlgili alan yazın incelendiğinde hizmet hatası ile ilgili tanımlamaların büyük çoğunluğu müşteri beklentisine göre yapılmaktadır. Dolayısıyla hizmet hatasının önlenmesi konusunda genellikle hizmet üreten kurumlar dikkate alınmakta, hizmeti sunan personel ile bunlardan yararlanan tüketiciler bu sürece pek fazla dahil edilmemektedir.

Yukarıdaki açıklamalardan da anlaşılacağı gibi hizmet hataları üretim, sunum ve tüketim aşamalarına göre çeşitlilik göstermektedir. Hizmet sektöründe faaliyet gösteren turizm işletmelerinde hizmet hataları dört (4) ana başlık altında sınıflandırılmaktadır. Buna göre (Hoffman, 2006; Olcay \& Özekici, 2015; Hodgetts, 1997; Hodge, Anthony, \& Gales, 2002);

1. Servis Sisteminden Kaynaklanan Hatalar: Bu hatalar doğrudan ürün veya hizmetin hazırlanma sürecinde kalitesiz malzemelerin kullanılması, üretimde yanlış yöntemlerin tercih edilmesi ve zamana kavramının dikkate alınmaması sonucu oluşan hatalardır.

2. Müşteri İsteklerinin Karşılanmamasından Kaynaklanan Hatalar: Herkes özel olduğunu hissetmek ister. Bundan dolayı müşteriye özel ürün ve hizmetlerin sunulmaması, taleplerinin uygun şartlarda karşılanmaması sonucunda oluşan hatalardır. Ayrıca görgü kurallarına uymayan ve diğer müşterileri rahatsız eden, art niyetli kişilerin neden olduğu hatalar da bu grupta değerlendirilmektedir.

3. Personel Davranışlarından Kaynaklanan Hatalar: İşletmede çalışan personel, kurumları başarıya ulaştıran ve hataları minimize eden kişilerdir. Personelin müşteri taleplerini yanlış veya eksik alması, ürün ve hizmetleri hatalı fiyatlandırması, temizlik ve hijyen kurallarına dikkat etmemesi gibi faktörlerden kaynaklanan hatalardır.

4. Kurumun Organizasyon Yapısından Kaynaklanan Hatalar: İşletmelerin organizasyon yapıları, departmanlar ve işgörenlerin sorumluluklarını, iş bölümünü ve etkinliğini belirleyen en önemli unsurlardandır. Organizasyon yapısı, işletmenin amaçlarına ulaşmasına yardımcı olacak stratejik kararların alınmasını, uygulanmasını ve denetimini de kolaylaştırmaktadır. Dolayısıyla yönetim kademesinde yer alan bireylerin yetersizlikleri veya kurumsal yapıdaki belirsizlikler de özellikle faaliyet aşamasında işletmelerde birçok hatanın meydana gelmesine neden olabilir. 
Ayrica kurumsal ortamdan kaynaklanan hatalar da bulunmaktadır. Bunlar 1sitma-soğutma sisteminin elverişli olmaması, müzik yayınında ses düzeyinin iyi ayarlanmaması, havalandırmanın yetersiz olması, temizlik ve hijyen kurallarına uyulmamas1 gibi unsurlarda hizmet hatas1 olarak değerlendirilmektedir. Bu tür hatalar büyük bir olumsuzluktur ve kurumsal itibara önemli zararlar vermektedir. Dolayısıyla hizmet hatalarının sınıflandırılması, hataların tanımlanması ve gerekli önlemlerin alınmasını kolaylaştırmaktadır. Sınıflandırılan ve zamanında önlem alınan hatalar, müşteri memnuniyetinin artmasına, kurumsal itibarın yükselmesine önemli katkılar yapmaktadır.

\section{II. Hizmet Hatası Telafi Stratejileri}

Hizmet hatası telafi stratejileri kurumların, ürün ve hizmet sunarken müşteri beklentilerini karşılayamadığında, onların memnuniyetini kazanmak için planlanan süreç olarak tanımlanmaktadır (Krishna, Lazarus, Sharma, \& Dangayach, 2012). Hizmet hatası telafisi, hizmet sağlayıcısının müşteri şikayetine neden olan olumsuzluklar karşısında verilen tepki olarak da tanımlanmaktadır (Grönroos, 1988). Hizmet hata telafisinin amacı, tatminsizlik yaşayan müşteriyi tatmin aşamasına getirmek olarak açıklanmaktadır. Hizmet telafisi, hizmet hatalarına karşı işletmelerin müşteriyle iş̧ ilişkisini sürdürmek için yaptığı eylemlerdir (Schweikhart, 1993). Çünkü müşteriyle iş ilişkisini sürdürmek öncelikle müşteri tatmini, sonrasında ise sadakatini sağlamaktadır (Bearden \& Teel, 1983).

Kurum yöneticileri şikâyet olmadan problemlerin varlığından haberdar olmayabilir ve müşteri memnuniyetini sağlayamayabilir. Bundan dolayı hizmet telafisi, hizmet hatalarını gösterme işlemi ile ilgilidir. Hizmet telafisi, şikâyetleri üretken bir şekilde karş1lamak ve müşterinin kurumla olan problemini çözmek için uygulanan tüm eylemler olarak görülebilir (Schoefer \& Ennew, 2003).

Hizmet sağlayan kurumun, oluşan hizmet hatalarına karşı sergilediği davranışların ve eylemlerin tamamı, hizmet telafi stratejilerini oluşturmaktadır. Bu stratejilerin içeriği kuruma, müşteriye ve hataya göre hiçbir şey yapmamakla, gereken her şeyi yapmak arasında geniş bir yelpazede yer alabilir. Telafi stratejilerinin amacı, memnuniyetsizlik yaşayan müşterinin işletme ile ilgili olumsuz algılarının değiştirilmesi ve tatmini sağlanarak tekrar kazanma ihtimalini arttırmaktır. Müşterinin gelecek davranışları hatadan ziyade hataya karşı işletmenin reaksiyonuna göre belirlenmektedir. Verilecek bu ilk tepki ile birlikte hizmet telafi stratejileri tek ya da beraber kullanılabilen değişik şekillerde gerçekleşmektedir. Bunlar; oluşan hatayı kabul edip özür dilemek, hatanın çözümü veya müşterinin bu hatadan etkilenmemesi için yardımcı olmak ve hatadan kaynaklanan zararın giderilmesidir (Abdullah, Manaf, Yusuf, Ahsan, \& Azam, 2014).

Müşteriler gerçekleşen hata karşısında işletmenin müşteri beklentisini ve bu beklentinin karşılanıp karşılanamadığını anlayıp özür dilemesi beklenmektedir. Samimi bir özür, müşteriler için genellikle işletmenin konuyla ve müşteriyle ilgili duyarlı olduğu anlamını taşır. Ancak özür dilemek sadece küçük ölçekli hataların telafisini giderebilir. Büyük hataların telafisi için ise sadece ilk adımı oluşturabilir (Blodgett, Hill, \& Tax, 1997).

Etkili bir hizmet telafisi için 4 davranıştan söz edilmektedir. Bunlar; (1) hatanın ne olduğunu anlamak, (2) hatanın sebebini açıklamak, (3) uygun zamanda ve şekilde özür dilemek, (4) birtakım ikramlarda bulunmak veya belli oranda indirim yapmaktır (Bitner, Booms, \& Tetreault, 1990). Müşterinin hatayla ilgili bilgilendirmesini ve şikâyetini "dinleme", hataya neyin sebep olduğunu "açıklama" ve hizmet hatası karşısında işletmenin üzgün olduğunu ifade edecek şekilde "özür dileme" hatanın telafisi için gerekli unsurlardandır (Swanson \& Scott, 2001). Hizmet hata telafi stratejileri; (1) tepki; hatayı kabullenip empati kurarak olumlu bir tepki vermek, (2) bilgi; müşteriyi dinleyerek hatanın tekrarlanmamasına dair garanti vermek ve müşteriyi hataya dair bilgilendirmek, (3) eylem; hatanın telafisi konusunda bir faaliyet yürüterek hatanın giderilmesini sağlamak (4) tazminat; sembolik bir tazminat, hediye veya ücret iadesi yapmak şeklinde sınıflandırılmaktadır (Bowen \& Johnson, 1999).

Telafiler, müşterilerin memnuniyetini hizmet hatasının hiç yaşanmadığı bir durumdan daha yüksek seviyeye çıkarabilir. Bu durum "telafi paradoksu" olarak adlandırılmaktadır. Diğer yandan gerçekleştirilen telafi müşterilerin memnuniyetsizliklerini de artırabilir. Bu duruma ise "çifte sapma" 
şeklinde ifade edilmektedir (Ok, Back, \& Shanklin, 2006). Bundan dolayı gerçekleştirilen telafi uygulamasından sonra müşterinin memnuniyet duyması büyük önem taşımaktadır.

\section{III. Konaklama İşletmelerinde Hizmet Hatası ve Telafi Stratejileri}

Turizm işletmelerinde hizmetin ve ürünün üretilmesi ile tüketilmesi genellikle eş zamanlı olduğundan hizmet hatasının oluşma ihtimali oldukça yüksektir (Çalışkan, 2013). Ayrıca turizm işletmelerinde hizmet genellikle bölünmez yapıdadır; yani hizmeti sağlayan tek bir kişi veya departman yoktur. Bu durum hizmetin müşteriye ulaştırılma sürecinde kontrolü zorlaştırmakta, alınabilecek önlemlerde koordinasyon zafiyetine yol açmaktadır (Çanakgöz, 2008:17). Turizm işletmelerinde ürün ve hizmetler stoklanamadığından hizmet hatalarının daha sık yaşanmasına neden olmaktadır. Turizm sektörünün emek yoğun olması, birçok faktörün kontrol edilebilirliğinin kısıtlı olması gibi etmenler de hizmet hatalarının daha kolay ortaya çıkmasına yol açmaktadır (Kambur, 2018).

Hizmet hatalarının sık gerçekleşmesi, soyut ürün ve hizmet üreten konaklama işletmelerinin kurumsal itibarının zedelenmesine, maddi ve manevi kayıplara neden olabilir. Ayrıca en küçük bir hatadan dolayı kaybedilecek müşteri, uğraşılması gereken yasal prosedürler, kurum hakkındaki olumsuz eleştiriler de kurumun hedeflerine ulaşmasına engel teşkil edebilir. Bundan dolayı etkin hizmet hatası telafi stratejileri mevcut müşteriyi kaybetmemek, yeni müşteriler kazanmak, gelecekte oluşabilecek hataları önlemek, kurumsal imajın zedelenmesini engellemek gibi birçok avantaj oluşturabilir. Çünkü hatanın telafi edilmesiyle memnuniyeti sağlanan müşterinin sadakati artar, yapacağı olumlu eleştiriler, yeni müşterilerin kazanılmasına da katkı sağlayabilir.

Oluşan hizmet hatasından müşterinin en az düzeyde etkilenmesi veya hiç etkilenmemesi için hızlı bir şekilde müşteriye yardımcı olmak maliyeti en az ve en etkili telafi yöntemidir. Müşteri memnuniyetsizliğinin, yani hatanın sebebini anlayıp hızlı bir şekilde çözüm üretmek, müşteri memnuniyetini tekrar sağlayacaktır. Örneğin tatil veya başka bir amaçla konaklama işletmesine gelen konuğa zamanında oda tahsisinin yapılmaması mağduriyetine neden olabilir. Bu durumda hataya maruz kalan kişiyi geçici olarak benzer veya üst seviyede başka bir odada ağırlamak, mağduriyetin giderilmesine ve işletme ile arasında olumlu bir etkileşimin oluşmasına vesile olabilir. Bu gibi ürün ve hizmet değiştirme, indirim yapma veya ücret almama gibi maddi çözümler, telafi stratejileri içinde tazminat olarak kabul edilmektedir. Aynı şekilde servis edilen ürünü beğenmeyen birisinin ürününü yenisi ile değiştirmek, kaldığı odada teknik aksaklıklarla karşılaşan müşteriye ücretsiz konaklama hediye etmek, indirim yapmak veya hediye vermek de benzer stratejilerindendir. Ancak bu durum tam tersi bir sonuçta oluşturabilir. Art niyetli müş̧eriler bu yönteme başvurarak haksız kazanç da elde edebilirler.

\section{ARAŞTIRMANIN YÖNTEMI}

Konaklama işletmelerinde uygulanan hizmet hatası telafi stratejilerinin kurumsal itibara etkisini ölçmek için hazırlana bu çalışma aşağıdaki sürece göre gerçekleştirilmiştir.

\section{I. Araştırmanın Amacı ve Önemi}

İnsan gücüne dayalı ürün ve hizmet sağlayan işletmeler, bu süreç içerisinde bir takım aksaklıklar yaşamaktadır. Bu aksaklıklar ürünün alıcısında ya da hizmetin sağlandığı kişilerde memnuniyetsizliğe neden olabilmektedir. Bu tür hizmetlerin sağlandığ aşamaların herhangi bir etabında karşılaşılan eksiklikler veya beklentilerin tam olarak karşılanamaması sonucu ortaya çıkan sorun, hizmet hatası olarak tanımlanmaktadır. Konaklama işletmelerinde oluşan hizmet hatalarının giderilmesi ve tüketici beklentilerinin karşılanması, işletmelerin hedeflerine ulaşmasını ve itibarını 
sürdürülebilir hale getirmektedir. Bundan dolayı bu çalışma hizmet hatası telafi stratejilerinin kurumsal itibara etkisini incelemek amacıyla hazırlanmıştır. Ayrıca turizm odaklı seyahatlerde bulunanların işletmeleri neden tercih ettiği ve karşılaştıkları sorunların nasıl giderildiği de incelenmiştir. Araştırmadan elde edilen bulgular sadece konaklama işletmeleri için değil, ilgili diğer sektör ve işletmelere de katkı sağlaması beklenilmektedir.

\section{II. Araştırmanın Evren ve Örneklemi}

Araştırmanın evreni olarak sıklıkla seyahat eden ve farklı niteliklere sahip konaklama işletmelerinden yararlanan turistler oluşturmaktadır. Araştırma kolayda örneklem yöntemiyle 400 kişiye ulaşılmıştır. Elde edilen verilerin bir kısmı eksik bilgi içerdiğinden değerlendirmeye alınmamış, sadece 392 kişinin vermiş olduğu cevaplar araştırmada kullanılmıştır. Evren büyüklüğü 10000 olan araştırmalarda $\pm \% 5$ payı ile 384 kişiye ulaşılması gerekmektedir (Ural \& Kılıç, 2013). Dolayısıyla 392 kişiden elde edilen veriler örneklem için yeterli olarak kabul edilmektedir.

\section{III. Veri Toplama Aracı}

Araştırma verileri anket yöntemiyle toplanmıştır. İlgili yazın incelenmiş Hoffman ve Bateson (2010); Keller (1998); Davidow (2014); Black \& Kelley (2009); Maher \& Sobh (2014) tarafindan yapılan araştırmalardan yararlanılarak anket soru formu oluşturulmuştur. Anket soru formunda katılımcıların demografik özellikleri, konaklama işletmelerinde karşılaştıkları hizmet hataları, bu hataların telafi stratejileri işletmelerin itibarlarıyla ilgili olmak üzere toplam 32 soru yer almaktadır. Anket soru formu kullanılarak araştırma için gerekli olan veriler Mart-Nisan 2019 tarihinde konaklama işletmelerinin ürün ve hizmetlerinden yararlanan turistlerden elde edilmiştir.

\section{IV. Araştırmanın Sınırılılıkları}

Her araştırmada olduğu gibi bu çalışmada da bir takım eksiklik ve sınırlılıkların olması doğaldır. Konaklama işletmelerinde gerçekleşen hizmet hatası ile ilgili telafi stratejilerinin kurumsal itibara etkisini ölçmek için hazırlanan bu çalışmanın sınırlılıkları aşağıda özetlenmektedir:

$\checkmark \mathrm{Bu}$ araştırma konaklama işletmelerinde tatil tecrübesi yaşayan kişiler ile sınırlıdır.

$\checkmark \mathrm{Bu}$ araştırmanın sonuçları, çalışma kapsamında yer alan kişilerin vermiş olduğu cevaplar ile sinirlidir.

$\checkmark$ Araştırmanın güvenirliliği, yapılan analizler ve yorumlar ile sınırlıdır.

\section{V. Araştırmanın Hipotezleri}

Konaklama işletmelerinde uygulanan hizmet hatası telafi stratejilerinin kurumsal itibara etkisini belirlemek için hazırlanan bu çalışma için belirlenen hipotezler şu şekilde belirlenmiştir:

$H_{1}$ : Hizmet hatası telafi strateji ile ilgili düşünceler, cinsiyete göre anlamlı farklılık gösterir.

$\mathrm{H}_{2}$ : Kurumsal itibar hakkındaki düşünceler, cinsiyete göre anlamlı farklılık gösterir.

$H_{3}$ : Katılımcıların yaşları ile hizmet hatası telafi stratejileri ve kurumsal itibar ile ilgili düşüncelerinde anlamlı farklılık vardır.

$H_{4}$ : Katılımcıların eğitim durumları ile hizmet hatası telafi stratejileri ve kurumsal itibar hakkındaki düşüncelerinde anlamlı farklılık vardır.

$H_{5}$ : Katılımciların gelir durumlarıla hizmet hatası telafi stratejileri ve kurumsal itibar hakkındaki düşüncelerinde anlamlı farklılık vardır.

$H_{6}$ : Hizmet hatası telafi stratejileri ile kurumsal itibar arasında anlamlı bir ilişki vardır.

$H_{7}$ : Hizmet hatası telafi stratejilerinin kurumsal itibara olumlu etkisi bulunmaktadır. 


\section{VI. Araştırmanın Güvenilirlik Analizi}

Araştırma verilerinin güvenirliğini ölçmek için Cronbach's Alpha Katsayısı tercih edilmiştir. Ölçeğin Cronbach's Alpha katsayısı 0,00-0,40 aralığında ise güvenilir değil, 0,40-0,60 aralığında olduğunda düşük güvenirlikte, $0,60-0,80$ arasında oldukça güvenilir, 0,80-1,00 aralığında olduğunda ise yüksek derecede güvenilir olarak değerlendirilmektedir (Kılıç, 2016: 46). Hizmet hatası ile ilgili ölçeğin Cronbach's Alpha katsayısı 0,787 olduğundan oldukça güvenilir olduğu anlaşılmaktadır. Kurumsal itibar ile ilgili ölçeğin Cronbach's Alpha değeri de 0,849 olarak hesaplanmış ve ölçeğin yüksek düzeyde güvenilir olduğu görülmektedir.

\section{ARAŞTIRMANIN BULGULARI}

\section{I. Demografik Özelliklere İlişkin Bulgular}

$\mathrm{Bu}$ araştırma kapsamında yer alan kişilerin demografik özelliklerini belirlemek için Tablo-1 hazırlanmıştır. Buna göre katılımcıların \% 51 erkek, \% 49'u da kadınlardan oluşmaktadır. Turizm amaçlı seyahate katılanların yarıdan fazlası $(\% 54,8) 25$ ve daha küçük yaştaki kişilerdir. Ayrıca araştırma kapsamında yer alanların büyük bir çoğunluğu lisans veya lisansüstü eğitim seviyesine sahiptir. Bu sonuca göre turizm eğitimli ve kültürlü kişilerin tercih ettiği bir faaliyet olduğu söylenebilir. Katılımcıların \% 12,0'si (47 kişi) ortalama aylık gelir ile ilgili soruya cevap vermemiştir. Gelir durumu ile ilgili diğer bilgiler ise aşağıdaki tabloda görülmektedir.

Tablo 1: Demografik Özellikler

\begin{tabular}{|l|l|r|r|}
\hline \multicolumn{2}{|c|}{} & \multicolumn{1}{|l|}{ N } & \multicolumn{1}{|c|}{$\%$} \\
\hline \multirow{4}{*}{ Cinsiyet } & Erkek & 200 & 51,0 \\
\cline { 2 - 4 } & Kadın & 192 & 49,0 \\
\hline \multirow{5}{*}{ Yaş } & 25 ve alt1 & 215 & 54,8 \\
\cline { 2 - 4 } & $26-35$ & 98 & 25,0 \\
\cline { 2 - 4 } & $36-45$ & 37 & 9,4 \\
\cline { 2 - 4 } & 46 ve üstü & 40 & 10,3 \\
\cline { 2 - 4 } & Cevapsiz & 2 & 0,5 \\
\hline \multirow{5}{*}{ Oğitim durumu } & Lise ve alt düzey & 71 & 18,1 \\
\cline { 2 - 4 } & Lisans & 203 & 51,8 \\
\cline { 2 - 4 } & Lisansüstü & 118 & 30,1 \\
\hline \multirow{5}{*}{ Ortalama gelir } & 150 Dolardan az & 32 & 8,2 \\
\cline { 2 - 4 } & $151-250$ & 71 & 18,1 \\
\cline { 2 - 4 } & $251-350$ & 60 & 15,3 \\
\cline { 2 - 4 } & $351-450$ & 59 & 15,1 \\
\cline { 2 - 4 } & $451-550$ & 42 & 10,7 \\
\cline { 2 - 4 } & 551 Dolar ve üstü & 81 & 20,7 \\
\cline { 2 - 4 } & Cevapsiz & 47 & 12,0 \\
\hline
\end{tabular}

\section{II. Hizmet Hatasına İlişkin Bulgular}

Araştırmanın bu bölümünde katılımcıların hizmet hatası ile ilgili düşünceleri değerlendirilmiştir. Buna göre hizmet hatası en fazla restoran, kat hizmetleri ve resepsiyon işlemlerinde gerçekleşmektedir. Araştırmaya kapsamında yer alan kişilerin sadece \% 5,1'i konaklama işletmelerinde hiç hizmet hatası ile karşılaşmadığını belirtmişlerdir. Katılımcıların büyük bir bölüm en az 2 kez hizmet hatasına maruz kaldıkları görülmektedir. Konaklama işletmelerinde hizmet hatası genel olarak temizlik ve hijyen kurallarına dikkat edilmemesi, kullanılan araç ve gereçlerin kalitesiz olması veya arızalı olmasından kaynaklanmaktadır. Hizmet hatası ile karşılaşanlar tepkisini ilk olarak departman yetkilisine veya işletme yöneticisine iletmektedirler. 
Katılımcıların \% 62'si hizmet hatası ile karşılaştıkları işletmeye tekrar gitmeyeceğini ifade ederken, $\%$ 25,8'i de aynı işletmeye tekrar gitme konusunda kararsız olduklarını belirtmektedirler.

Tablo 2: Hizmet Hatası ile İlgili Bulgular

\begin{tabular}{|c|c|c|c|}
\hline & & $\mathbf{N}$ & $\%$ \\
\hline \multirow{5}{*}{$\begin{array}{l}\text { Hizmet hatasını } \\
\text { hangi departmanda } \\
\text { yaşadınız* }\end{array}$} & Resepsiyon & 125 & 31,9 \\
\hline & Restoran & 138 & 35,2 \\
\hline & Bar & 65 & 16,6 \\
\hline & Kat Hizmetleri & 125 & 31,9 \\
\hline & Diğer & 6 & 1,5 \\
\hline \multirow{6}{*}{$\begin{array}{l}\text { Kaç kez hizmet } \\
\text { hatası ile } \\
\text { karşılaştınız }\end{array}$} & $1 \mathrm{Kez}$ & 98 & 25,0 \\
\hline & $2 \mathrm{Kez}$ & 132 & 33,7 \\
\hline & $3 \mathrm{Kez}$ & 59 & 15,1 \\
\hline & $4 \mathrm{Kez}$ & 8 & 2,0 \\
\hline & $5 \mathrm{Kez}$ ve daha fazla & 75 & 19,1 \\
\hline & Hiç karılaşmadım & 20 & 5,1 \\
\hline \multirow{6}{*}{$\begin{array}{l}\text { Ne gibi hizmet } \\
\text { hatası ile } \\
\text { karşılaştınız* }\end{array}$} & İşletmede kullanılan araç gereçler kalitesiz, eksiz veya arızalıydı & 131 & 33,4 \\
\hline & İşletmede temizlik ve hijyen sorunu vardı & 162 & 41,3 \\
\hline & Çalışanlar saygısız ve nazik değillerdi & 97 & 24,7 \\
\hline & İşletmede genel güvenlik sorunu vardı & 22 & 5,6 \\
\hline & Ürün ve hizmetleri yüksek fiyattan satmaya çalıştılar & 40 & 10,2 \\
\hline & Hatalı sipariş aldılar & 72 & 18,4 \\
\hline \multirow{6}{*}{$\begin{array}{l}\text { Hizmet hatası } \\
\text { kimden } \\
\text { kaynakland } 1\end{array}$} & İşletme yetkisinden & 107 & 27,3 \\
\hline & Departman müdürlerinden & 85 & 21,7 \\
\hline & Hizmet sunan personelden & 157 & 40,1 \\
\hline & Diğer müşterilerden & 29 & 7,4 \\
\hline & Kendimden & 13 & 3,3 \\
\hline & Diğer & 1 & 0,3 \\
\hline \multirow{6}{*}{$\begin{array}{l}\text { Hizmet hatasına } \\
\text { nasıl tepki } \\
\text { gösterdiniz* }\end{array}$} & Departman yetkilisine şikâyet ettim & 151 & 38,5 \\
\hline & İşletme yetkisine şikâyet ettim & 125 & 31,9 \\
\hline & Durumu sosyal medyadan paylaştım & 13 & 3,3 \\
\hline & Yasal yollara başvurdum & 21 & 5,4 \\
\hline & Aileme, yakın arkadaşlarıma ve çevremdeki insanlara bahsettim & 138 & 35,2 \\
\hline & Hiç bir şey yapmadım & 34 & 8,7 \\
\hline \multirow{3}{*}{$\begin{array}{l}\text { Hizmet hatası olan } \\
\text { tesise tekrar gider } \\
\text { misiniz? }\end{array}$} & Evet & 48 & 12,2 \\
\hline & Hayır & 243 & 62,0 \\
\hline & Kararsızım & 101 & 25,8 \\
\hline
\end{tabular}

*Bu sorularda katılımcılar birden fazla seçeneği işaretlemişlerdir

\section{III. Araştırma ile İlgili T Testi Analizi}

Araştırmada katılımcıların cinsiyetleriyle hizmet hatası hakkındaki düşüncelerinde anlamlı bir farklı1ığın olup olmadığı da araştırılmıştır. Bunun için bağımsız örneklem t-testi yapılmış ve Tablo3 hazırlanmıştır. Buna göre katılımcıların hizmet hatası ile ilgili sadece "Şikâyette bulunacağım yere veya kişiye kolayca ulaştım" $(\mathrm{p}=0,004)$ ve "Şikâyette bulunduğum kişi sorunumu istekli bir şekilde dinledi" $(\mathrm{p}=0,001)$ ifadelerinde anlamlı bir farklılık tespit edilmiş, diğerlerinde ise herhangi bir farkl11ık görülmemektedir. Yapılan bu analiz sonucunda araştırmanın $H_{l}$ numaralı hipotezinin $\mathrm{kabul}$ edildiği anlaşılmaktadır.

Tablo 3: Cinsiyet Değişkeni ile Hizmet Hatası Telafi Stratejileri Hakkındaki Düşünceler

\begin{tabular}{|c|c|c|c|c|c|c|}
\hline Iffadeler & Cinsiyet & $\mathbf{N}$ & Ort. & SS. & SD & $\mathbf{P}$ \\
\hline \multirow{2}{*}{$\begin{array}{l}\text { Şikâyette bulunacağım yere veya kişiye kolayca } \\
\text { ulaşım }\end{array}$} & Erkek & 200 & 2,225 & 0,921 & \multirow{2}{*}{390} & \multirow{2}{*}{0,004} \\
\hline & Kadın & 192 & 2,521 & 1,083 & & \\
\hline \multirow{2}{*}{$\begin{array}{l}\text { İşletme yönetimi şikâyetim ile ilgili hemen } \\
\text { ilgilendiler }\end{array}$} & Erkek & 200 & 2,535 & 1,093 & \multirow{2}{*}{390} & \multirow{2}{*}{0,443} \\
\hline & Kadın & 192 & 2,448 & 1,152 & & \\
\hline \multirow{3}{*}{$\begin{array}{l}\text { Şikâyette bulunduğum kişi beni anlayışla karşıladı } \\
\text { ve saygılı davrandı }\end{array}$} & Erkek & 200 & 2,620 & 1,154 & \multirow{2}{*}{390} & \multirow{2}{*}{0,143} \\
\hline & Kadın & 192 & 2,453 & 1,092 & & \\
\hline & Erkek & 200 & 2,690 & 1,077 & 390 & 0,001 \\
\hline
\end{tabular}




\begin{tabular}{|c|c|c|c|c|c|c|}
\hline $\begin{array}{l}\text { Şikâyette bulunduğum kişi sorunumu istekli bir } \\
\text { şekilde dinledi }\end{array}$ & Kadın & 192 & 2,344 & 1,052 & & \\
\hline \multirow{2}{*}{$\begin{array}{l}\text { Sorunun kaynağı ile ilgili tatmin edici açıklama } \\
\text { yapıldı }\end{array}$} & Erkek & 200 & 2,945 & 1,191 & \multirow{2}{*}{390} & \multirow{2}{*}{0,079} \\
\hline & Kadın & 192 & 2,740 & 1,114 & & \\
\hline \multirow{2}{*}{$\begin{array}{l}\text { Yaşadığım sorun karşısında eş değerde çözüm } \\
\text { sunuldu }\end{array}$} & Erkek & 200 & 2,785 & 1,107 & \multirow{2}{*}{390} & \multirow{2}{*}{0,306} \\
\hline & Kadın & 192 & 2,672 & 1,079 & & \\
\hline \multirow{2}{*}{$\begin{array}{l}\text { Yaşadığım sorun işletmeden hizmet aldığım süre } \\
\text { içerisinde çözüldü }\end{array}$} & Erkek & 200 & 3,005 & 1,246 & \multirow{2}{*}{390} & \multirow{2}{*}{0,755} \\
\hline & Kadın & 192 & 2,969 & 1,038 & & \\
\hline \multirow{2}{*}{$\begin{array}{l}\text { İşletme karşılaştı̆̆ım sorunla ilgili yetkili kişilerin } \\
\text { yaklaşımı bana güven verdi }\end{array}$} & Erkek & 200 & 2,810 & 1,082 & \multirow{2}{*}{390} & \multirow{2}{*}{0,218} \\
\hline & Kadın & 192 & 2,672 & 1,136 & & \\
\hline
\end{tabular}

Katılımcıların cinsiyetleri ile turizm deneyimi yaşadıkları konaklama tesislerinin kurumsal itibarı hakkındaki düşüncelerinde anlamlı bir farklılığın olup olmadığını araştırmak için de Tablo-4 hazırlanmıştır. Yapılan analiz sonucuna göre katılımcılar "İsletmede müş̧teri kayıtları ve hesapları doğru yapilır" ( $\mathrm{p}=0,032)$, "Personelin hizmet sunarken ismim ile hitap etmesi beni mutlu eder" $(\mathrm{p}=0,009)$ ve "Işsletme toplumsal olaylara karşı duyarlıdır" $(\mathrm{p}=0,040)$ ifadeleri ile ilgili düşünceleri cinsiyete göre farklılık göstermektedir. Bu üç ifade de erkek katılımcılar, kadınlara göre kurumsal itibar ile ilgili daha olumlu düşünceye sahip olduğu görülmektedir. Diğer ifadeler de ise herhangi bir farklılık tespit edilmemiştir. Aşağıdaki tablo incelendiğinde araştırmanın $H_{2}$ numaralı hipotezinin kabul edildiği görülmektedir.

Tablo 4: Cinsiyet ile Kurumsal İtibar Hakkındaki Düşünceler

\begin{tabular}{|c|c|c|c|c|c|c|}
\hline İfadeler & Cinsiyet & $\mathbf{N}$ & Ort. & SS. & SD & $\mathbf{P}$ \\
\hline \multirow{2}{*}{ Hizmet aldığım işletme çok kaliteliydi } & Erkek & 200 & 2,790 & 1,082 & \multirow{2}{*}{390} & \multirow{2}{*}{0,238} \\
\hline & Kadın & 192 & 2,656 & 1,156 & & \\
\hline \multirow{2}{*}{$\begin{array}{l}\text { Hizmet aldığım işletmede çalışan personel alanında } \\
\text { uzman kişilerdir }\end{array}$} & Erkek & 200 & 3,155 & 1,089 & \multirow{2}{*}{390} & \multirow{2}{*}{0,183} \\
\hline & Kadın & 192 & 3,010 & 1,053 & & \\
\hline \multirow{2}{*}{ İşletmede herkese standart kalitede hizmet sunulur } & Erkek & 200 & 3,115 & 1,157 & \multirow{2}{*}{390} & \multirow{2}{*}{0,341} \\
\hline & Kadın & 192 & 3,005 & 1,123 & & \\
\hline \multirow{2}{*}{ İşletmede müşteri kayıtları ve hesapları doğru yapılır } & Erkek & 200 & 2,500 & 1,027 & \multirow{2}{*}{390} & \multirow{2}{*}{$\mathbf{0 , 0 3 2}$} \\
\hline & Kadın & 192 & 2,281 & 0,989 & & \\
\hline \multirow{2}{*}{$\begin{array}{l}\text { İşletmede kullanılan makine ve tüm teçhizatlar } \\
\text { sorunsuz çalışır }\end{array}$} & Erkek & 200 & 2,925 & 1,070 & \multirow{2}{*}{390} & \multirow{2}{*}{0,466} \\
\hline & Kadın & 192 & 2,844 & 1,133 & & \\
\hline \multirow{2}{*}{$\begin{array}{l}\text { Tüm kademedeki personel müşterilere yardımcı } \\
\text { olmak için isteklidirler }\end{array}$} & Erkek & 200 & 2,775 & 1,072 & \multirow{2}{*}{390} & \multirow{2}{*}{0,956} \\
\hline & Kadın & 192 & 2,781 & 1,191 & & \\
\hline \multirow{2}{*}{$\begin{array}{l}\text { Personelin hizmet sunarken ismim ile hitap etmesi } \\
\text { beni mutlu eder }\end{array}$} & Erkek & 200 & 2,555 & 1,355 & \multirow{2}{*}{390} & \multirow{2}{*}{0,009} \\
\hline & Kadın & 192 & 2,229 & 1,097 & & \\
\hline \multirow{2}{*}{ İşletme her konuda güvenilir bir tesistir. } & Erkek & 200 & 2,665 & 1,038 & \multirow{2}{*}{390} & \multirow{2}{*}{0,685} \\
\hline & Kadın & 192 & 2,708 & 1,072 & & \\
\hline \multirow{2}{*}{ İşletme toplumsal olaylara karşı duyarlıdır } & Erkek & 200 & 2,805 & 1,016 & \multirow{2}{*}{390} & \multirow{2}{*}{$\mathbf{0 , 0 4 0}$} \\
\hline & Kadın & 192 & 2,599 & 0,966 & & \\
\hline \multirow{2}{*}{ Hizmet aldığım işletme sektörde lider konumundadır } & Erkek & 200 & 3,070 & 1,054 & \multirow{2}{*}{390} & \multirow{2}{*}{0,978} \\
\hline & Kadın & 192 & 3,073 & 1,026 & & \\
\hline \multirow{2}{*}{$\begin{array}{l}\text { İşletme halk arasında ve sosyal medyada olumlu bir } \\
\text { izlenime sahiptir }\end{array}$} & Erkek & 200 & 2,765 & 1,032 & 390 & 0.503 \\
\hline & Kadın & 192 & 2,698 & 0,945 & 390 & 0,503 \\
\hline & Erkek & 200 & 2,790 & 1,068 & 300 & 0231 \\
\hline Hizmet aldıgım işletme yenılige ve degişıme açıktır & Kadın & 192 & 2,661 & 1,051 & 390 & 0,231 \\
\hline Hizmet aldığım işletme verdiği sözleri ve hizmetleri & Erkek & 200 & 2,755 & 1,005 & 390 & 0376 \\
\hline sorunsuz yerine getirir & Kadın & 192 & 2,667 & 0,967 & 390 & $0,3 / 6$ \\
\hline Tesisin işletme belgesinde, tanıtımında ve & Erkek & 200 & 2,895 & 1,171 & & \\
\hline reklamlarında abartı yoktur & Kadın & 192 & 2,990 & 1,033 & 390 & 0,398 \\
\hline
\end{tabular}




\section{IV. Araştırma ile İlgili Anova Test Sonuçları}

Araştırmanın bu bölümünde ikiden fazla bağımsız grubun bağımlı bir değişken ile arasındaki değişkene göre ortalamaları karşılaştırılmış ve değişkenler arasındaki farkın belirli bir güven düzeyinde anlamlı olup olmadığı araştırılmıştır. Bunun için de Anova testi kullanılmıştır.

Katılımcıların yaş grupları ile hizmet hatası ve kurumsal itibar ile ilgili düşüncelerinde anlamalı bir farklılığın olup olmadığını belirlemek için Anova Post-hoc testi yapılmıştır. Bu test sonucunda hazırlanan Tablo-5'e göre katılımcıların yaşları ile hizmet hatası hakkındaki düşüncelerinde herhangi anlamlı bir farklılık tespit edilmemiştir. Katılımcıların kurumsal itibar hakkındaki düşüncelerinde ise anlamlı bir farkl1lık tespit edilmiştir. Farklılık ise 36-45 yaş grubu ile 46 ve üstü yaş grubunda yer alanlar arasında görülmüştür. Bu sonuca göre araştırma için belirlenen $\mathrm{H}_{3}$ numaralı hipotezin kabul edildiği anlaşılmaktadır.

Tablo 5: Yaş ile Hizmet Hatası ve Kurumsal İtibar Hakkındaki Düşünceler

\begin{tabular}{|c|c|c|c|c|c|c|c|c|}
\hline & & Yaşlar & $\mathbf{N}$ & Ort. & SS. & $\mathbf{F}$ & $\mathbf{P}$ & Farklılık \\
\hline \multirow{4}{*}{$\begin{array}{l}\text { Hizmet } \\
\text { Hatası }\end{array}$} & $\mathbf{A}$ & 25 ve alt1 & 215 & 2,617 & 0,743 & \multirow{4}{*}{1,809} & \multirow{4}{*}{, 145 } & \multirow{4}{*}{---- } \\
\hline & B & $26-35$ & 98 & 2,736 & 0,679 & & & \\
\hline & $\mathrm{C}$ & $36-45$ & 37 & 2,797 & 0,446 & & & \\
\hline & D & 46 ve üstü & 40 & 2,500 & 0,702 & & & \\
\hline \multirow{4}{*}{$\begin{array}{l}\text { Kurumsal } \\
\text { İtibar }\end{array}$} & $\mathbf{A}$ & 25 ve alt1 & 215 & 2,751 & 0,606 & \multirow{4}{*}{2,723} & \multirow{4}{*}{0,044} & \multirow{4}{*}{ C $>$ D } \\
\hline & B & $26-35$ & 98 & 2,835 & 0,653 & & & \\
\hline & $\mathrm{C}$ & $36-45$ & 37 & 2,969 & 0,550 & & & \\
\hline & D & 46 ve üstü & 40 & 2,595 & 0,702 & & & \\
\hline
\end{tabular}

Araştırma kapsamında yer alanlar farklı düzeyde eğitime durumuna sahiptirler. Bu farklılığın hizmet hatası ve kurumsal itibar ile ilgili düşüncelerde farklılık oluşturup oluşturmadığını anlamak için de Tablo-6 hazırlanmıştır. Aşağıda yer alan tablo incelendiğinde, katılımcılar farklı düzeyde eğitime sahip olsalar dahi hem hizmet hatası hem de kurumsal itibar ile ilgili düşüncelerinde anlamlı bir farklılık oluşmamaktadır. $\mathrm{Bu}$ sonuç araştırmanın $\mathrm{H}_{4}$ numaralı hipotezinin ret edildiğini göstermektedir.

Tablo 6: Eğitim Durumu ile Hizmet Hatası ve Kurumsal İtibar Hakkındaki Düşünceler

\begin{tabular}{|c|c|c|c|c|c|c|c|c|}
\hline & & Eğitim & $\mathbf{N}$ & Ort. & SS. & $\mathbf{F}$ & $\mathbf{P}$ & Farklılık \\
\hline \multirow{3}{*}{$\begin{array}{l}\text { Hizmet } \\
\text { Hatası }\end{array}$} & $\mathbf{A}$ & Lise & 71 & 2,585 & 0,721 & \multirow{3}{*}{0,583} & \multirow{3}{*}{0,559} & \multirow{3}{*}{ Yok } \\
\hline & B & Lisans & 203 & 2,651 & 0,682 & & & \\
\hline & $\mathrm{C}$ & Lisans Üstü & 118 & 2,698 & 0,722 & & & \\
\hline \multirow{3}{*}{$\begin{array}{l}\text { Kurumsal } \\
\text { İtibar }\end{array}$} & $\mathbf{A}$ & Lise & 71 & 2,667 & 0,547 & \multirow{3}{*}{1,424} & \multirow{3}{*}{0,242} & \multirow{3}{*}{ Yok } \\
\hline & B & Lisans & 203 & 2,794 & 0,616 & & & \\
\hline & C & Lisans Üstü & 118 & 2,818 & 0,684 & & & \\
\hline
\end{tabular}

Farklı gelir grubunda yer alan kişilerin hem hizmet hatası hem de kurumsal itibar ile ilgili düşüncelerinde anlamlı bir farklılı̆̆ın olup olmadığını belirlemek için aşağıdaki tablo hazırlanmıştır. Hazırlanan Tablo-7'ye göre değişik düzeyde gelir elde eden kişilerin hizmet hatası ile ilgili düşüncelerinde anlamlı bir farklılığın olduğu belirlenmiş ve $H_{5}$ numaralı hipotezin kabul edildiği doğrulanmıştır. Ancak değişik düzeyde gelire sahip olanların kurumsal itibar ile ilgili düşüncelerinde ise her hangi anlamlı bir farklılık belirlenmemiştir. 
Tablo 7: Gelir Seviyesi ile Hizmet Hatası ve Kurumsal İtibar Hakkındaki Düşünceler

\begin{tabular}{|c|c|c|c|c|c|c|c|c|}
\hline & & Gelir Düzeyi & $\mathbf{N}$ & Ort. & SS. & $\mathbf{F}$ & $\mathbf{P}$ & Farklılık \\
\hline \multirow{6}{*}{$\begin{array}{l}\text { Hizmet } \\
\text { Hatası }\end{array}$} & $\mathbf{A}$ & 150 ve daha az & 32 & 2,406 & 0,710 & \multirow{6}{*}{2,743} & \multirow{6}{*}{0,019} & \multirow{6}{*}{$\mathbf{E}>\mathbf{A}$} \\
\hline & B & $151-250$ & 71 & 2,694 & 0,877 & & & \\
\hline & $\mathbf{C}$ & $251-350$ & 60 & 2,740 & 0,603 & & & \\
\hline & D & $351-450$ & 59 & 2,561 & 0,585 & & & \\
\hline & $\mathbf{E}$ & $451-550$ & 42 & 2,908 & 0,512 & & & \\
\hline & $\mathbf{F}$ & 551 ve daha fazla & 81 & 2,793 & 0,700 & & & \\
\hline \multirow{6}{*}{$\begin{array}{l}\text { Kurumsal } \\
\text { İtibar }\end{array}$} & $\mathbf{A}$ & 150 ve daha az & 32 & 2,710 & 0,648 & \multirow{6}{*}{1,276} & \multirow{6}{*}{0,274} & \multirow{6}{*}{ Yok } \\
\hline & B & $151-250$ & 71 & 2,796 & 0,676 & & & \\
\hline & C & $251-350$ & 60 & 2,880 & 0,577 & & & \\
\hline & D & $351-450$ & 59 & 2,723 & 0,532 & & & \\
\hline & $\mathbf{E}$ & $451-550$ & 42 & 2,971 & 0,479 & & & \\
\hline & $\mathbf{F}$ & 551 ve daha fazla & 81 & 2,884 & 0,700 & & & \\
\hline
\end{tabular}

\section{V. Hizmet Hatası Telafi Stratejileri ile Kurumsal İtibar Arasındaki İlişki Analizi}

Konaklama tesislerinde karşılaşılan hizmet hatası telafi stratejileri ile kurumsal itibar arasındaki ilişkiyi incelemek amacıyla korelasyon analizi uygulanmıştır. Yapılan analiz sonucunda Tablo-8 incelendiğinde, konaklama işletmelerinde hizmet hatası telafi stratejileri ile kurumsal itibar arasında doğru yönlü anlamlı bir ilişki görülmektedir $(p<0,001)$. Değişkenler arasındaki ilişkinin derecesi ise ( $\mathrm{r}=530)$ orta düzeydedir (Kul, 2019). Yani hizmet hatası telafi stratejileri uygulandıkça işletmelerin kurumsal itibarı da artmaktadır. Bu sonuç araştırmanın $H_{6}$ numaralı hipotezinin kabul edildiğini göstermektedir.

Tablo 8: Hizmet Hatası Telafi Stratejileri ile Kurumsal İtibar Arasındaki İlişki

\begin{tabular}{|c|c|c|c|}
\hline & & Hizmet Hatası Telafi S. & Kurumsal İtibar \\
\hline \multirow{3}{*}{$\begin{array}{c}\text { Hizmet Hatası } \\
\text { Telafi S. }\end{array}$} & Pearson K. & 1 &, $530^{* *}$ \\
\hline & $\mathrm{P}$ & &, 000 \\
\hline & $\mathrm{N}$ & 392 & 392 \\
\hline \multirow{3}{*}{ Kurumsal İtibar } & Pearson K. &, $530^{* *}$ & 1 \\
\hline & $\mathrm{P}$ &, 000 & \\
\hline & $\mathrm{N}$ & 392 & 392 \\
\hline
\end{tabular}

\section{VI. Hizmet Hatası Telafi Stratejileri ile Kurumsal İtibara Etkisi}

Konaklama işletmelerinde uygulanan hizmet hatası telafi stratejilerinin kurumsal itibara olan etkisini belirlemek amaciyla regreasyon analizi yapılmıştır. Analiz sonucunda hazırlanan Tablo-9'a göre hizmet hatası telafi stratejilerinin kurumsal itibara pozitif ve anlamlı düzeyde etkisinin olduğu belirlenmiştir. Elde edilen verilere göre hizmet hatası telafi stratejilerinde bir (1) birimlik artışın kurumsal itibar üzerinde 0,530 artışa neden olduğu anlaşılmaktadır. Bu sonuca göre araştırmanın $H_{7}$ numaralı hipotezinin kabul edildiği görülmektedir.

Tablo 9: Hizmet Hatası Telafi Stratejilerinin Kurumsal İtibara Etkisi

\begin{tabular}{|c|c|c|c|c|c|}
\hline \multirow[t]{2}{*}{ Model } & \multicolumn{2}{|c|}{$\begin{array}{c}\text { Standardize } \\
\text { edilmemiş katsayılar }\end{array}$} & \multirow{2}{*}{$\begin{array}{c}\begin{array}{c}\text { Standardize edilmiş } \\
\text { katsayılar }\end{array} \\
\text { Beta } \\
\end{array}$} & \multirow[t]{2}{*}{ t Değeri } & \multirow{2}{*}{$\begin{array}{l}\text { Anlam } \\
\text { Düzeyi }\end{array}$} \\
\hline & B & Std. Hata & & & \\
\hline (Sabit) & 1,006 & 0,137 & & 7,350 & 0,000 \\
\hline Kurumsal İtibar & 0,593 & 0,048 & 0,530 & 12,342 & 0,000 \\
\hline
\end{tabular}




\section{SONUÇ VE ÖNERILER}

Konaklama işletmeleri insan gücüne dayalı ürün ve hizmet üretmektedir. Bu süreçte bir takım olumsuzlukların yaşanma ihtimali oldukça yüksektir. Olumsuzluklara karşı her kişi ve kurumun farklı tepkileri olmaktadır. Karşılaşılan hizmet hatalarını telafi etmeye yönelik uygulanan stratejiler, işletmeler için bir takım avantajlar oluşturabileceği gibi dezavantajlara da neden olabilir. Bundan dolayı bu çalışma, turizm sektöründe faaliyet gösteren konaklama işletmelerinde oluşabilecek hizmet hatalarının kurumsal itibar üzerinde bırakacağı etkileri belirlemek amacıyla hazırlanmıştır. Çalışmada hizmet hatalarının konaklama işletmelerinin her departmanında olabileceği sonucu elde edilmiştir. En fazla hatanın ise restoran, resepsiyon ve barda olabileceği belirlenmiştir. Konaklama işletmelerinde hizmet hatalarının genel olarak temizlik ve hijyen ile ilgili olduğu anlaşılmaktadır. Hizmet hatalarının yaşanmasına en fazla neden olan unsurun ise hizmeti sunan personelin olduğu görülmektedir. Hizmet hataları ile karşılaşanların büyük bir bölümü tepkilerini departman yetkililerine ileterek göstermektedirler. Hizmet hatası ile karşılaşanların bu olumsuz durumu çevresindekilerine anlatıp işletmenin itibarını olumsuz yönde etkileyenlerin sayısı da azımsanamayacak düzeydedir. Ayrıca araştırmada hizmet hatası ile karşılaşan kişilerin, ilgili işletmeyi tekrar tercih etmeyecekleri de belirlenmiştir.

Hizmet hatası telafi uygulamalarının kişiler üzerinde bırakacağı etki bireylerin yaş ve cinsiyetine göre farkl1lık göstermektedir. Çünkü orta yaş grubunda yer alan kişilerin hizmet beklentileri oldukça yüksek seviyededir (Duffy, Miller, \& Bexley, 2006). Hizmet hatası telafi stratejilerinde farklı uygulamaların olduğu ve bunun bireyler üzerinde değişik etkilerinin olduğu belirtilmektedir. Erkekler için en etkili telafi stratejinin tazminat, kadınlar için ise bunun yeterli olmadığ1 görülmektedir (Mattila, Cho, \& Ro, 2009). Bu durum araştırma sonucunda da doğrulanmıştır. Kişilerin hizmet hatası hakkındaki düşünceleri yaş ve cinsiyete göre anlamlı düzeyde farkl11ık göstermektedir.

Hizmet hatası telafi stratejileri, müşterilere kurumun kaliteli ve garantili hizmet verdiği izlenimi oluşturur (Çanakgöz, 2008). Araştırma verileri sonucunda hizmet hatası telafi stratejilerinin kurumsal itibar ile pozitif yönlü bir ilişkisinin olduğu anlaşılmaktadır. Ayrıca hizmet hatası ile karşılaşan konuklar için belirlenen telafi stratejileri, kurumsal itibarın artmasına da yardım etmektedir.

Hizmet hatası telafi stratejileri müşteri memnuniyeti ve bağl1lığının \% 88 artmasına neden olmaktadır (Tsai \& Su, 2009). Turizm işletmelerinde üretim ile tüketim genellikle aynı anda gerçekleşmektedir. Dolayısıyla her an bir takım olumsuzlukların yaşanması muhtemeldir. Bundan dolayı etkin bir telafi stratejisinin belirlenmesi, konuk memnuniyeti için önemli avantajlar sağlayabilir.

Konaklama işletmelerinde en etkili telafi stratejisi olarak tazminat, özür dileme, açıklama vb. uygulamaların olduğu belirtilmektedir (Fu, Wu, Huang, Song, \& Gong, 2015). Hizmet hatası ile karşılaşan konuk ile hemen iletişim kurmak, bir takım ikramlarda veya indirimlerde bulunmak sadece hata ile karşılaşan konukları değil, diğer konukların işletmeye karşı düşüncelerini de olumlu etkileyebilir. Bunun sonucunda artan kurumsal itibar, işletmelerin yoğun rekabet ortamında pazar payını artırmasına ve hedeflerine ulaşmasına önemli katkılar sağlayabilir. 
Etik Beyanı

: Bu çalışmanın tüm hazırlanma süreçlerinde etik kurallara uyulduğunu yazarlar olarak beyan ederiz. Aksi bir durumun tespiti halinde ÖHÜIIIBF Dergisinin hiçbir sorumluluğu olmadığını ve tüm sorumluluğun çalışmanın yazarlarına ait olduğunu bildiririz. İlgili çalışmada kullanılan veriler 2019 yılında toplanmış ve analiz edilmiştir. Veriler 2020 yllı öncesi toplandı̆̆ından etik kurul kararı gerekmemektedir.

Yazar Katkıları : Doç. Dr. Erkan AKGÖZ, çalışmada I, II, III ve IV bölümlerinde ve (verilerin analiz vs. gibi) aşamalarında katkı sağlamıştır. Darya KRASNIKOVA, çalışmada I ve IV bölümlerinde ve (veri toplama, analiz vs. gibi) aşamalarında katkı sağlamıştır. 1. yazarın katkı oranı: \%60, 2. yazarın katkı oranl: $\% 40$.

Çıkar Beyanı : : : Yazarlar arasında çıkar çatışması yoktur.

Ethics Statement $\quad:$ Authors declare that the ethical rules are followed in all preparation processes of this study. In the event of a contrary situation, ÖHÜIBF Journal has no responsibility and all responsibility belongs to the author (s) of the study. The data used in the relevant study were collected in 2019 and the data were analyzed. Since the data were collected before 2020, there is no need for an ethical board decision.

Author Contributions : Assoc. Dr. Erkan AKGÖZ contributed in the sections I, II, III and IV and in the stages (such as analysis of data etc.). Darya KRASNIKOVA contributed to the sections I and IV and in the stages (such as data collection, analysis etc.). Contribution rate of the 1st author: 60\%, Contribution rate of the 2 nd author: $40 \%$

Conflict of Interest $\quad$ : There is no conflict of interest among the authors.

\section{KAYNAKÇA}

Abdullah, M. A., Manaf, N. H., Yusuf, M.-B. O., Ahsan, K., \& Azam, M. F. (2014). Determinants of customer satisfaction in retail banks in New Zealand: an empirical analysis using structural equation modeling. Global Economy and Finance Journal, 7(1), 63-82. doi:10.21102/gefj.2014.03.71.04

Akgöz, E., \& Solmaz, B. (2010). Turizm işletmelerinde itibar yönetimi. S.Ü. IIIBF. Sosyal ve Ekonomik Araştırmalar Dergisi, 10(19), 23-41. Erişim adresi: https://dergipark.org.tr/tr/download/articlefile $/ 289156$

Aydemir, B. A. (2008). İşletmelerin yeni rekabet aracı olarak kurumsal itibar. "işs, Güç" Endüstri Ilişskileri ve Insan Kaynaklarl Dergisi, $10(2), \quad 28 . \quad$ Erişim adresi: http://www.repman.com.tr/tr/wpcontent/uploads/2017/04/isletmelerin-yeni-rekabet-araci-olarak-itibar.pdf

Bateson, J. E., \& Hoffman, K. D. (2011). Services marketing. New York: South-Western Cengage Learning.

Bearden, W. O., \& Teel, J. E. (1983). Selected determinants of consumer satisfaction and complaint reports. Journal of Marketing Research, 20(1), 21-28. Retrieved from https://www.jstor.org/stable/pdf/3151408.pdf

Bitner, M., Booms, B. H., \& Terreault, M. S. (1990). The service encounter: diagnosing favorable and unfavorable incidents. The Journal of Marketing, , 71-84. Retrieved from https://www.jstor.org/stable/pdf/1252174.pdf

Black, H., \& Kelley, S. W. (2009). A storytelling perspective on online customer reviews reporting service failure and recovery. Journal of Travel \& Tourism Marketing, 26(2), 169-179. doi: $10.1080 / 10548400902864768$

Blodgett, J. G., Hill, D. J., \& Tax, S. S. (1997). The effects of distributive, procedural, and interactional justice on postcomplaint behavior. Journal of Retailing, 73(2), 185-210. doi: 10.1016/S0022-4359(97)900038

Bowen, D., \& Johnson, R. (1999). Internal service recovery : developing a new construct. International Journal of Service Industry Management, 10(2), 118-131. doi:10.1108/09564239910264307

Çalışkan, O. (2013). Restoran işletmelerinde hizmet hataları ve hizmet telafi stratejileri ve müşteri memnuniyeti ilişkisi. Seyahat ve Otel İ̧sletmeciliği Dergisi, 65-83. Erişim adresi: https://dergipark.org.tr/tr/download/article-file/117438 

etkisi. Ömer Halisdemir Üniversitesi İktisadi ve İdari Bilimler Fakültesi Dergisi, 13(3), 446-461.

Çanakgöz, G. (2008). Hizmet telafisinin müşteri memnuniyeti üzerine etkileri: Türk bankacllk sektörü uygulaması. (Yüksek Lisan Tezi) Ege Üniversitesi Sosyal Bilimler Enstitüsü, İzmir.

Davidow, M. (2014). The a-craft model of organizational responses to customer complaints and their impact on post-complaint customer behavior. Journal of Customer Satisfaction, Dissatisfaction and Complaining Behavior, 27. Retrieved from https://jcsdcb.com/index.php/JCSDCB/article/view/132

Duffy, J. A., Miller, J. M., \& Bexley, J. B. (2006). "Banking customers" varied reactions to service recovery strategies. International Journal of Bank Marketing, 24(2), 112-132. doi:10.1108/02652320610649923

Ekici, K., \& Yüce, A. (2007). CRM müşsteri iliş̧kileri yönetimi. Ankara: Savaş Yayınevi.

Fu, H., Wu, D. C., Huang, S. S., Song, H., \& Gong, J. (2015). Monetary or nonmonetary compensation for service failure? a studyof customer preferences under various loci of causality. International Journal of Hospitality Management, 46, 55-64. doi:10.1016/j.ijhm.2015.01.006

Grönroos, C. (1988). New competition in the service economy: the five rules of service. International Journal of Operations \& Production Management, 8(3), 9-19. doi:10.1108/eb054821.

Hodge, B. J., Anthony, W. P., \& Gales, L. M. (200). Organization theory: a Strategic approach. 6th. Edition, Prentice Hall, New Jersey.

Hodgetts, R. M. (1997). Yönetim: teori, süreç ve uygulama. (Çev., C.Çetin ve E. C. Mutlu) İstanbul: Der Yayinevi

Hoffman, K., \& Bateson, J. E. (2010). Service marketing: concepts, strategies and cases (4 bs). South-Western College Pub.

Kadıbeşegil, S. (2006). İtibar yönetimi. İstanbul: MediaCat Kitapları.

Kambur, E. (2018). Müşterilerin hizmet hatası ve hizmet telafisine yönelik algılarının demografik özellikler doğrultusunda tespit edilmesi. Akademik Bakış Dergisi, (69), 49-68. Erişim adresi: https://dergipark.org.tr/tr/download/article-file/568436

Karakılıç, N. Y. (2005). Kurumsal itibarın müşteri tercihleri üzerine etkileri: Afyon'da perakende sektöründe faaliyet gösteren işletmeler üzerine bir araştırma. Afyon Kocatepe Üniversitesi, İ̈BF Dergisi, 7(2), 181196. Erişim adresi: https://dergipark.org.tr/tr/download/article-file/19075

Karaköse, T. (2007). Kurumların DNA'sı itibar ve yönetimi. Ankara: Nobel Yayın Dağıtım.

Keller, K. L. (1998). Strategic Brand Management: Building, Measuring, and Managing Brand Equity. Prentice-Hall International.

Kılıç, S. (2016). Cronbach'ın alfa güvenirlik katsayısı. Journal of Mood Discorders, 47-46. doi: 10.5455/jmood.20160307122823

Krishna, A., Lazarus, D., Sharma, S., \& Dangayach, G. S. (2012). Service recovery system gaps. International Journal of Sciences: Basic and Applied Research (IJSBAR), 6(1), 48-57 Retrieved from https://pdfs.semanticscholar.org/6237/06c583a8a972555713c814509602d29ff785.pdf

Kul, S. (2019). Korelasyon Analizi. [Web log post]. Retrieved from http://www.p005.net/analiz/korelasyonanalizi

Maher, A. A., \& Sobh, R. (2014). The role of collective angst during and after a service failure. Journal of Services Marketing, 28(3), 223-232. doi:10.1108/JSM-10-2012-0203

Mattila, A. S., Cho, W., \& Ro, H. (2009). The joint effects of service failure mode, recovery effort, and gender on customers' post-recovery satisfaction. Journal of Travel and Tourism Marketing, 26(2), 120-128. doi:10.1080/10548400902862002

Munyoro, G., \& Magada, E. (2016). The significance of corporate reputation management in the public sector: a case study of national social security autority (NASSA). Researchjournali's Journal of Management, 4(4), 1-20. Retrieved from http://www.researchjournali.com/view.php?id=2637

Ok, C., Back, K.-J., \& Shanklin, C. W. (2006). Service recovery paradox: implications from an experimental study in restaurant setting. Journal of Hospitality \& Leisure Marketing, 21. doi: $10.1300 / J 150 \mathrm{v} 14 \mathrm{n} 03 \quad 03$

Okay, A., \& Okay, A. (2005). Halkla ilişkiler, kavram, strateji ve uygulamaları. İstanbul: Der Yayınları.

Olcay, A., \& Özekici, Y. K. (2015). Yiyecek-içecek işletmelerinde hizmet hataları, telafi yöntemleri ve müşteri memnuniyeti iliş̧kisi (Gaziantep örneği). Uluslararası Sosyal Araştırmalar Dergisi, 8(41), 1254-1268. Erişim adresi: http://www.sosyalarastirmalar.com/cilt8/sayi41_pdf/6iksisat_kamu_isletme/olcay_atinc_yakupkemalo zekici.pdf 
Rose, C., \& Thomsen, S. (2004). The impact of corporate reputation on performance: some Danish evidence. Europen Management Journal, 22(2), 201-210. doi:10.1016/j.emj.2004.01.012

Saylı, H., \& Uğurlu, Ö. Y. (2007). Kurumsal itibar ve yönetsel etik ilişkisinin analizine yönelik bir değerlendirme. Süleyman Demirel Üniversitesi İ̈BF Dergisi, 12(3), 75-96. Erişi̇m adresi: https://dergipark.org.tr/en/download/article-file/194789

Schoefer, K., \& Ennew, C. (2004). Customer evaluations of tour operators' responses to their complaints. Journal of Travel\&Tourism Marketing, 17(1), 83-92. doi:10.1300/J073v17n01_06

Schweikhart, S. B., Strasser, S., \& Kennedy, M. R. (1993). Service recovery in health service organizations. Hospital \& health services administration, 38(1), 3-21. Retrieved from https://pubmed.ncbi.nlm.nih.gov/10127293/

Swanson, S.R., \& Kelley, S. W. (2001). Service recovery attributions and word-of-mouth intentions. European Journal of Marketing, 35(1/2), 194-211. doi: 10.1108/03090560110363463

Torlak, Ö., Altunışık, R., \& Özdemir, Ş. (2014). Pazarlama ilkeleri ve yönetimi. İstanbul: Beta Basım Yayım.

Tsai, C.-T., \& Su, C.-S. (2009). Service failures and recovery strategies of Chain restaurants in Taiwan. The Service Industries Journal, 29(12), 1779-1796. doi:10.1080/02642060902793599

Ural, A., \& Kılıç, İ. (2013). Bilimsel araştırma süreci ve SPSS ile veri analizi (4. bs). Ankara: Detay Yayıncılık.

Williams, R. J., Schnake, M., \& Fredenberger, W. (2005). The impact of corporate strategy on a firm's reputation. Corporate Reputation Review, 8(3), 187-197. doi:10.1057/palgrave.crr.1540249. 